\title{
Historical Land Use, Nitrogen, and Coastal Eutrophication: A Paleoecological Perspective
}

\author{
Grace S. Brush
}

Received: 17 June 2008 /Revised: 24 September 2008 / Accepted: 30 September 2008 / Published online: 16 October 2008

(C) Coastal and Estuarine Research Federation 2008

\begin{abstract}
Organisms and chemicals preserved in sediment cores from the Chesapeake estuary in mid-Atlantic USA are consistent with a precolonial landscape covered with a diversity of forests and marshes, large and small. During the past 300 years, many of the wetlands have been drained, and the landscape was converted to agricultural fields and urban and suburban development. During this time, sources of nitrogen have diversified, and loadings have increased. Since precolonial time, the mesohaline estuary has become increasingly eutrophic and anoxic. Estuaries and coastal regions throughout the world have experienced similar conditions in their recent history. These changes are recorded in Chesapeake sediment cores by increases in ragweed pollen, dry taxa, sedimentation rates, nitrogen influxes, and a major change in estuarine autotrophs from benthic to planktonic. In many areas, attempts to reverse estuarine eutrophication and anoxia have centered on restoring streams and riparian areas and reducing fertilizer use on agricultural lands. However, data from soils and historical reports and the paleoecological record suggest that to reduce the effects of modern nitrogen inputs, it may be necessary to locate and enhance denitrifying areas throughout the watershed.
\end{abstract}

Keywords Estuary $\cdot$ Landscape $\cdot$ Paleoecology $\cdot$ Nitrogen fixation $\cdot$ Eutrophication $\cdot$ Anoxia $\cdot$ Denitrification

G. S. Brush $(\bowtie)$

Johns Hopkins University,

Baltimore, MD 21218, USA

e-mail: gbrush@jhu.edu

\section{Introduction}

An important and largely unanswered question in many coastal areas throughout the world is how can aquatic ecosystems be restored to functionally coupled autotrophic detrital food webs, where inorganic material is converted to organic by primary producers, used by consumers, and converted back to inorganic by decomposers and recycled to primary producers. The large coastal shellfish and fishery resource, which has provided food for much of the world's human populations, has been greatly reduced as excess nutrients and over-harvesting have altered energy flows through aquatic food webs. Excess nitrogen is a major cause of ecosystem deterioration both on land and in water and is particularly difficult to amend due to multiple sources, the complexity of nitrogen transformations, and the necessity of anaerobic conditions for its return to the atmosphere as elemental nitrogen, via denitrification (e.g., Vitousek et al. 1997; Galloway et al. 2004; Seitzinger et al. 2006). In this discussion, I concentrate on the Chesapeake Bay, a large estuary on the Atlantic coast of USA (Fig. 1). I use the stratigraphic record of organisms and materials preserved in Chesapeake Bay sediments spanning 1,000 to 14,000 years, along with available historical records (past 300 years; Fig. 2) to trace the history of changes associated primarily with nitrogen loadings into the estuary since precolonial time. I briefly review the known history of coastal eutrophication and deterioration worldwide. And finally, based on the historical and paleoecological records, I propose that a significant reduction in nitrogen both on the land and in the estuary can be accomplished most effectively by multiple denitrifying processors, both natural and engineering, positioned throughout the watershed. 

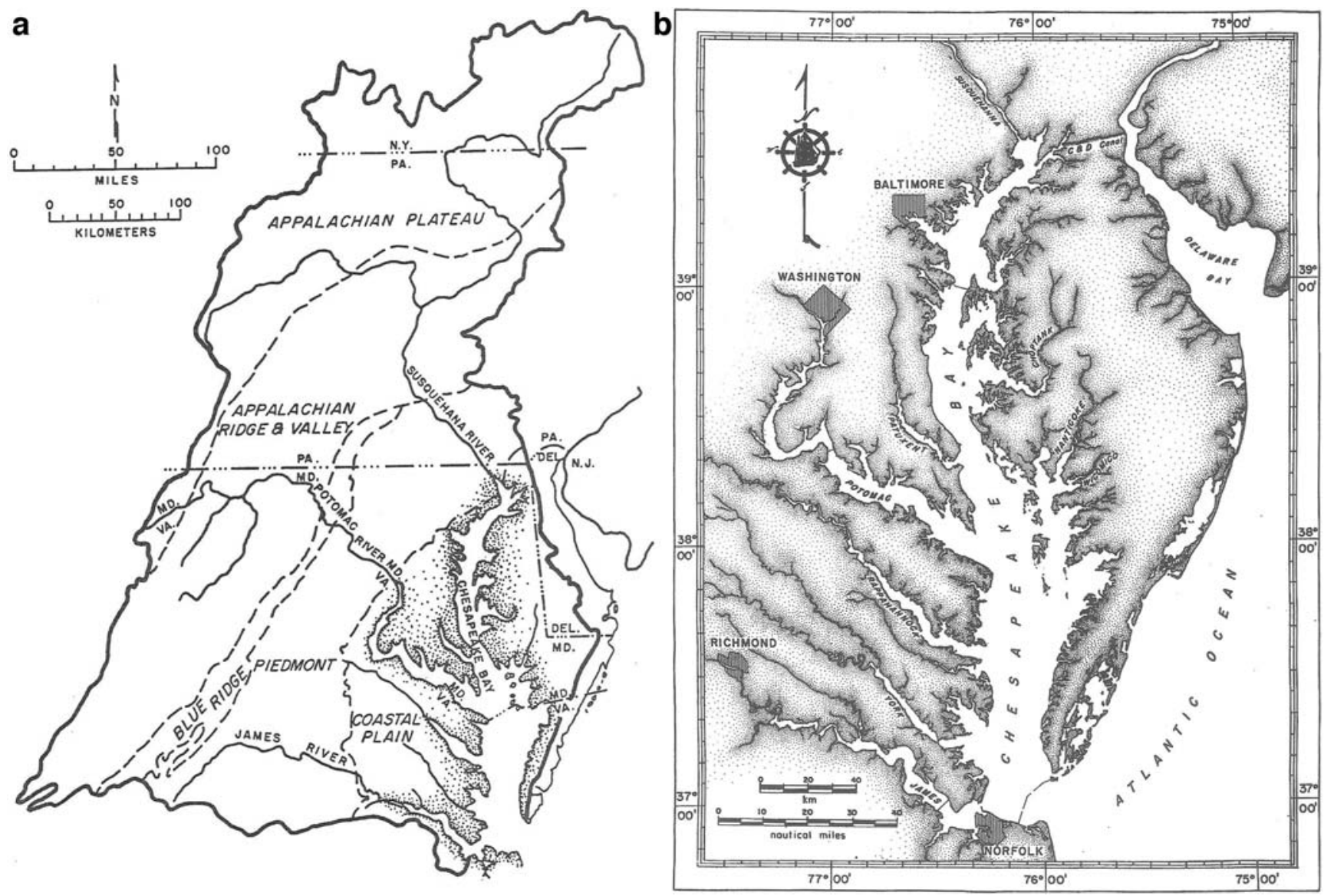

Fig. 1 a Map of Chesapeake Bay watershed; b map of Chesapeake Bay estuary

\section{The Evolution of the Chesapeake Watershed}

The Precolonial Landscape

The present Chesapeake estuary, like many estuaries throughout the world, is a creation of the last continental ice sheet that covered much of the Earth as recently as 18,000 years ago. As the glaciers retreated, sea level rose and estuaries formed along low-lying coasts. Pollen records from Chesapeake sediments extending back 14,000 years record changes in land vegetation that accompanied climate change as the glaciers retreated northward (Yuan 1995). The records show that the modern vegetation of eastern USA, established approximately 6,000 years ago, has not changed in the intervening time despite natural climate change and accompanying wind and fire disturbance. The first European settlers to arrive on the east coast of USA in the 1600s found a land almost entirely covered with a diversity of forests on a wide variety of soils, drained by an intricate and dense system of over 100,000 streams and 150 major rivers surrounded by large marshes. Native American populations were sparse in number, and the majority was fishermen and hunter-gatherers (Miller 2001). Beavers were abundant and important because of their ability
Fig. 2 a The Chesapeake watershed at different historical periods: precolonial up to 1650 showing a forested landscape with a large beaver population; early colonial when about $40 \%$ of the land was deforested for agriculture; intensive agriculture when up to $80 \%$ of the land was under cultivation; and urbanization when about half of the watershed is in forest and urban and suburban centers characterize some parts of the watershed (redrawn from Andrews 2008). b The increase in the human population. The data were derived from spatially allocating historical county census data from the US Census Bureau to inside the Bay watershed boundary. The spatial allocation was done using weighting factors derived from the 2000 Census Block Group database distributed to $30-\mathrm{m}$ residential road density cells (Peter Claggett, personal communication). c The historical record of land use (data from Chesapeake Bay Program). d Sales of fertilizer in the Chesapeake watershed (Elliott et al., unpublished data). e Historical record of nitrogen fluxes into the Potomac River (from Jaworski et al. 2007). f The historical record of the crab and oyster harvest (from Cronin 1986; Kennedy and Mountford 2001; and http:// archive.chesapeakebay.net/status/status07/crabharv\%202006_CBP. xls). g Pollen representation of land use in the upper estuary. h Paleoecological record of sedimentation rates in the upper estuary (redrawn from Brush 1989). i Pollen profile showing a gradual increase in dry taxa after colonization. $\mathbf{j}$ Nitrogen influx into the Chesapeake Bay (redrawn from Arnold 2003). k The change in the ratio of planktonic to benthic diatom species in the central mesohaline section of the estuary (redrawn from Cooper 1995) 


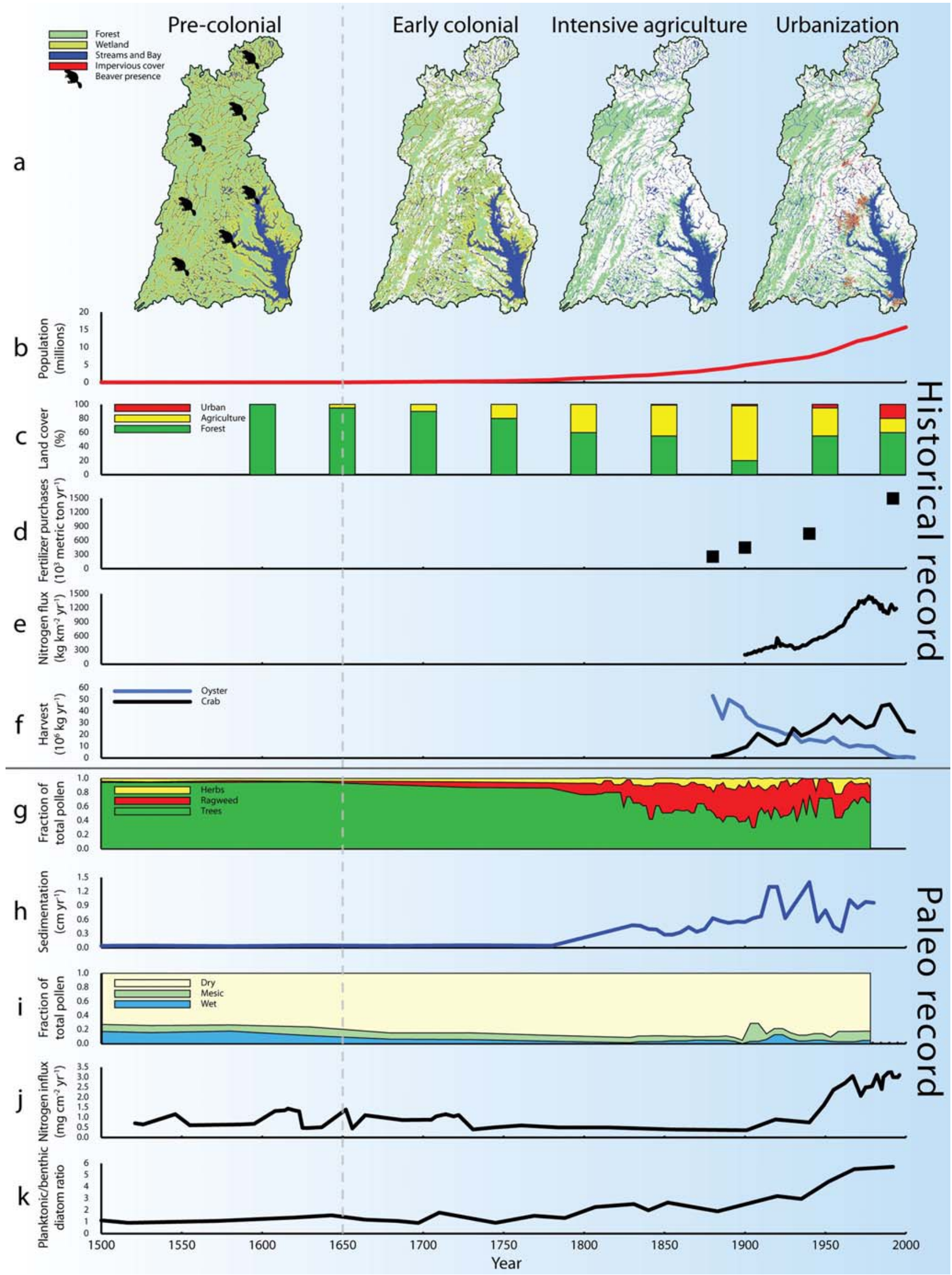


to alter landscape hydrology. Their activity of building local dams and impoundments on primarily first to fifth order streams resulted in a dynamic landscape mosaic with wetlands formed and abandoned multiple times (Morgan 1867). The beaver population in North America in precolonial time is estimated to have been between 60 and 400 million individuals within a geographic area of 15 million $\mathrm{km}^{2}$ (Naiman et al. 1988) or a minimum of four to 30 animals approximately every square kilometer, assuming a highly unlikely even distribution. The wetness of the land is evidenced by the presence of water lily pollen in dark organic layers exposed in stream banks that have radiocarbon dates of 1,700 years (Brush, unpublished data). The proximity of groundwater to the surface is also seen in springs along tributaries recorded on historical maps (Douglas 1897). The environment was wet and marshy throughout. The main source of available nitrogen was natural biological fixation, and the major loss term, after multiple cycles of use and reuse, was a return of elemental nitrogen to the atmosphere through denitrification (Richter and Markewitz 2001).

The pollen profiles show a primarily forested landscape in precolonial time, with a majority of non-arboreal plants consisting of wetland species. Among the plant species were nitrogen fixers such as alder (Alnus sp.), black locust (Robinia pseudo-acacia), and herbaceous legumes. Sedimentation rates were low, ranging between 0.01 and $0.1 \mathrm{~cm} /$ year. Nitrogen profiles from sedimentary cores show very small and in some cores variable influxes in precolonial time (Cooper 1993; Zimmerman and Canuel 2002; Arnold 2003). Relatively higher precolonial influxes, where they occur in the sediments, could have resulted from waste from the large beaver populations, which lived primarily in water. Diatom profiles from sediment cores reflect a high diversity of largely benthic species (Cooper 1995; Arnold 2003). Likewise, submerged macrophyte populations were consistently present for at least 1,000 years prior to colonization (Brush and Hilgartner 2000). There is no biologic evidence of light limitation from turbidity or of estuarine eutrophication in sediments deposited during this time.

The Landscape of the Early Colonists (Late Seventeenth to Early Eighteenth Century)

Early colonial agriculture, practiced from the late 1600 s to the mid 1700s, consisted first of subsistence farming followed by tobacco. Most farms were located along tributaries where soils were rich and transport easily available. During this period, small areas were cleared of forests by axe and seedlings planted with a hoe (Walsh 1989). Crops were grown on a plot of land in the following sequence: tobacco for 2 to 3 years followed by corn and grain also for 2 to 3 years. The plot was then abandoned, because soil fertility was believed to have decreased (Earle 1992). Next, a new plot was cleared for cultivation, allowing the original plot to lay fallow for about 20 years, when the soil was believed to have regained fertility and crops were again grown on it. During this period known as long fallow farming, at any one time, $<20 \%$ of the land was cleared (Froomer 1980; Walsh 1989). In the early eighteenth century, the declining European tobacco market and an increasing population resulted in growing more grain crops and less tobacco. Agriculture extended from the Coastal Plain into the Piedmont. By the 1700s, ports were established on the upper reaches of most tributaries for transport particularly of wheat (Gottschalk 1945; Brugger 1988). Biologically fixed nitrogen was still the major source of available nitrogen, with contributions from animal waste. Human populations were low (Ubelaker and Curtin 2001). By the early to mid 1700s, the beaver population in North America was essentially eliminated (Naiman et al. 1988).

The pollen record shows that forests still covered most of the landscape during the 1700s and into the early 1800 s. Agriculture is represented by a slight increase in ragweed pollen. Sedimentation rates remain low ranging from 0.2 to $0.5 \mathrm{~cm} /$ year, although higher than in precolonial time. There is no evidence of drying in the pollen profiles. Nitrogen profiles from the central Bay and tributaries show extremely low nitrogen influxes after 1750 possibly reflecting the greatly reduced waste produced by the beaver population. Denitrification rates would not have changed as the land would have still remained wet from existing dams, and draining for agriculture had not begun. Diatom populations remain predominantly benthic and unchanged from precolonial time, as do the submerged macrophyte populations, indicating that estuarine water quality had not changed since precolonial time.

\section{The Landscape Leading Up to and Including Intensive} Agriculture (1740-1930)

An important transformation in post-colonial agriculture was the invention and use of the plow, which by the late 1700s, was regularly used (Brugger 1988). The wooden plow, used between 1780 and 1820 , was replaced by the iron plow, which in turn was replaced by the steel plow, which cut deeply into the soil (Craven 1965). At this time, farms were small family operations consisting of grain and some tobacco crops and livestock (Walsh 1989). In the early nineteenth century, fallow farming was replaced by crop rotation. Later, burnt marl and lime and guano imported from South America beginning around 1820 (Cornwell et al. 1996) were used as fertilizers, allowing the cultivation of marginal lands generally consisting of poor soils on erodible slopes (Earle 1992). The amount of 
farmed land increased from $20 \%$ to $40-50 \%$ (Froomer 1980; Brush 1989; Walsh 1992). From 1880 to 1930, growing human populations along with the use of imported fertilizers and animal waste resulted in cultivation of $60 \%$ to $80 \%$ of the watershed (U.S. Census Data 1850-1975). Large heavily mechanized commercial farms replaced small family farms.

In addition to farming, trees were cut to produce charcoal used for the manufacture of iron, from the early 1700 s to the early to mid 1800 s in the northern Bay area. Chrome and iron were mined throughout the 1800 s (Vokes and Edwards 1974).

Demand for wood for building ships to export wheat primarily, as well as roads needed for transport on land, resulted in additional forest clearance. By the middle of the eighteenth century, eroded soil from agricultural lands was filling in the deep shipping channels of the upper tributaries of the Chesapeake. The port of Baltimore, established on the Patapsco River in 1706, was moved downstream in 1768 and again to its present location in 1799 , where it has remained a viable port only because it has been dredged periodically since 1815 (Gottschalk 1945). In 1870, the US Army Corps of Engineers began dredging other tributaries along both the eastern and western shores of the Chesapeake (Brugger 1988).

Chemically produced nitrogen fertilizers replaced guano after World War I and were regularly used except during World War II, when synthetic nitrogen was not available for fertilizers. During that time, compost and animal manure were used (Stevenson et al. 1999). Nitrogen was also introduced from combustible fuels needed to power the machines used to plant and harvest crops. There are very few quantitative data on the relative amounts of the different sources of nitrogen during this time. Records of tons of fertilizer purchased by county throughout the watershed based on various census data show an eightfold increase from 1880 to 1992 (Elliott et al. unpublished data). Nitrogen fluxes into the Potomac River doubled between 1907 and 1930 (Jaworski et al. 2007).

In addition to fertilizers and fuels contributing nitrogen to the watershed, animal manure was substantial throughout this largely agricultural watershed (e.g., Elliott and Brush 2006). Initially, human waste was disposed of in privies and cisterns. After 1880, septic systems were installed in areas of increasing population density. Hydrologic connectivity insured that much of the waste stored on land would eventually find its way into the estuary and tributaries. In 1911, the Back River Sewage Treatment Plant, built in a small tributary adjacent to Baltimore to service the metropolitan area, began operating, followed later by other sewage treatment plants throughout the region. Hence, nitrogen derived from human waste was discharged directly into estuarine waters. In addition, atmospheric nitrogen was reaching the Chesapeake watershed from power plants in the Midwestern part of the country, and increasing automobile transport was also adding substantially to the introduction of nitrogen compounds into the environment.

The expansion of agriculture to include almost all of the watershed meant that previously low wet areas and marshes were drained in order to create arable land. Streams were channelized so that adjacent floodplains, which contained rich soil for agriculture, were no longer flooded. These hydrologic changes paralleling the conversion of forest to grassland reduced the denitrifying capacity of the watershed at a time when biological nitrogen fixation increased with crop rotation and later was augmented by the introduction of nitrogen compounds from many sources.

The paleoecological record shows that the ratio of arboreal to non-arboreal (excluding ragweed) to ragweed pollen in sediment cores reflects the history of land use. Sedimentation rates increased according to the amount of land cleared and show a two- to tenfold increase during this period (Brush et al. 1982; Brush 1984, 1989). Nitrogen influxes in sediment cores also show continuing large increases with an initial peak in 1900, demonstrating a trajectory similar to measured nitrogen fluxes since 1900 in the Potomac River. Diatom populations began to shift from benthic to planktonic as eroded sediment decreased light penetration in the water column. At the same time, fertilizers, coupled with sediment eroded from agricultural fields, resulted in a proliferation of planktonic algal growth and further reduction in light for benthic plants. Eventually, the system flipped from a benthic dominated system to mainly a phytoplankton based pelagic system, with much of the energy from the autotrophic food chain metabolized by microorganisms in the water column or shunted to sediments where detrital remains of primary producers were also decomposed mainly by bacteria. This led to important habitat losses, including a massive shift in autotrophs from submerged macrophytes and benthic diatoms to phytoplankton, as the deeper waters became hypoxic and anoxic.

The Landscape of Afforestation and Urbanization (1930 to Present)

Forests began to grow back, beginning in the 1900s and continuing through the 1930s, as farms were abandoned due primarily to economic conditions. At the same time, the large wetlands in the Coastal Plain on the eastern shore of the Chesapeake were drained for additional cropland. It is estimated that the Bay has lost over one-half of its marshes since colonial time, not including wetlands due to beaver activity (USA EPA Chesapeake Bay Program). Today, percent forest cover in the Chesapeake watershed ranges from roughly $40 \%$ to $60 \%$ with the lower amount of forest cover in Maryland (Sprague et al. 2006). More recently, 
development (defined as the acreage taken out of forest and agriculture and generally referred to as suburban) has added another layer of change to the land. Between 1950 and 1980, 1.1 million hectares (of a total 16.2 million hectares) of the Chesapeake watershed were developed, and since that time, suburban and urban development has expanded to close to 3.2 million hectares (Andrews 2008). Housing developments and associated shopping centers and infrastructure have resulted in forest fragmentation, a reduction of agricultural land, and conversion of land to impervious surfaces. Initial urbanization prior to paving and asphalting resulted in sediment peaks in streams associated with peak discharges (Wolman 1967). Railroad and road building boosted sediment loads to the estuary (Khan and Brush 1994; Pasternack and Brush 1998). Total impervious surfaces in the watershed increased from over 240,000 hectares in 1990 to 350,000 hectares in 2000 and are projected to reach well over 400,000 hectares in 2010 (USA EPA Chesapeake Bay Program). This has had a dramatic effect on stream hydrology, as rain flows through streams at very high volumes and velocities, with only a fraction of the water infiltrating the ground, resulting in reduced groundwater recharge. As soils became drier and aerated and groundwater lowered, denitrifying capacities of riparian areas have been diminished (Groffman et al. 2002, 2003). Soil conservation, such as no-till farming practiced since the 1940s, has lessened sedimentation to some degree. Fertilizers continue to be used extensively, and pesticides were introduced in the 1950s. DDT was banned in 1972, but other chemicals are still used as herbicides on agricultural land and urban/suburban lawns.

Sources of nitrogen to the watershed diversified and inputs increased during this period. Atmospheric nitrogen contributes the greatest amount of nitrogen, with power plants the primary source and automobiles the secondary source (Elliott et al. 2007). Chemical fertilizers are the second largest contributor, followed by animal waste and municipal and industrial waste water (USA EPA Chesapeake Bay Program). The percentage of nitrogen from the different sources that are distributed in the receiving waters may differ from that which reaches the watershed.

Oyster and crab populations, as measured by harvest in millions of kilograms, have changed since the 1900s. The oyster harvest has been in a steady decline since the $1980 \mathrm{~s}$ and is almost non-existent at present except for hatcherysupported oyster bars in a few tributaries. The crab harvest increased until 1990 when it began a steep decline with no current indication of recovery (Cronin 1986; Kennedy and Mountford 2001; USA EPA Chesapeake Bay Program).

Pollen profiles show an increase in forest cover since the early 1900s, with most plants belonging to drier taxa. The sediment profiles show a decrease in sedimentation rates in general since the mid twentieth century. During this time, there has been an increase in nitrogen influxes followed by a decrease and a later increase, which persist to the present. Diatom populations are almost entirely planktonic. Submerged macrophytes disappeared in the Potomac by 1965 (Rybicki and Landwehr 2007), were gone from the Patuxent in the 1960s (Stankelis et al. 2003), and declined in the upper Bay in the 1960s and all but disappeared by 1972 (Bayley et al. 1975). By the early 1970s, submerged macrophytes experienced disastrous declines in numerous tributaries throughout the upper and middle Bay (Brush and Hilgartner 2000). Since then, recovery has been local and variable from year to year, for example, a 1980 recovery in the Potomac River (Rybicki and Landwehr 2007). Sediment chemistry, including total organic carbon and the degree of pyritization of iron indicate a large increase in anoxia since the mid twentieth century, over and above that which occurred following initial European colonization (Cooper and Brush 1991; Hagy et al. 2004; Kemp et al. 2005).

\section{Summary and Discussion}

Sediment, nitrogen, pollen, diatom, and seed profiles from sediment cores throughout the Chesapeake Bay suggest a precolonial nitrogen cycle consisting of a balance between biological nitrogen fixation and denitrification. This condition was maintained through periods of climate change such as the Medieval Warm Period 1,000 years ago and subsequent droughts. The landscape was for the most part wet and forested. In early precolonial time, the balance was maintained and according to the sediment record, did not change for a century or so while agriculture consisted of small farms separated by patches of forest. Later, crop rotation increased biological nitrogen fixation, and growing agricultural crops increased nitrogen uptake. But the paleoecological record of nutrients and diatoms preserved in estuarine sediments shows no change in estuarine water quality. Starting in the middle eighteenth century, draining of wetlands and floodplains to provide more arable land for an increasing population leading to the vast deforestation of eastern North America, changed landscape vegetation, hydrology, and geochemistry, so that opportunities for denitrification were greatly reduced. At the same time, along with greater biological fixation, sources of nitrogen increased, including guano, nitrate deposits, and later synthetic nitrogen. These changes are recorded in the sediment cores by increasing sedimentation rates, planktonic diatoms, and nitrogen influxes.

The basic reason for this change was the need to provide food for an increasing population. Even though the estuary supplied an abundance of various species of fish and shellfish, including striped bass, perch, shad, crabs, and oysters, human diets also require plant products, particu- 
larly grains, which are not the primary product of a forest ecosystem. Hence, the forests were changed to grasslands. This was accomplished by massive disturbance and huge subsidies in the form of fertilizers, drainage, and irrigation. The excess nutrients, along with sediment eroded off the land, led to eutrophication and anoxia and eventually extreme stress on the estuarine ecosystem.

Aquatic deterioration as described here, resulting primarily from fertilizers used on agricultural land, is not unique to the Chesapeake. Coastal regions throughout the world are experiencing similar difficulties, and most are not showing any notable recovery. In the Chesapeake, eutrophication has resulted mainly in hypoxia and anoxia. But eutrophication can also result in toxic algal blooms. Diaz and Rosenberg (2008) have reported more than 400 systems throughout the world where eutrophication has resulted in "dead zones" characterized by low dissolved oxygen and/or toxic algal blooms. However, the number of reported dead zones, as significant as it is, does not account for large areas of the Earth where monitoring is inadequate or non-existent, such as parts of Africa, Asia, and Latin America (Selman et al. 2008). Diaz and Rosenberg (2008) also report that in the USA and Europe where monitoring is more intense and has extended over a longer period of time, $78 \%$ of the continental US coastal area and $65 \%$ of Europe's Atlantic coast show varying degrees of eutrophication. The formation of dead zones is caused primarily by runoff of fertilizers from the land and an increased use of fossil fuel (Diaz and Rosenberg (2008), both of which are associated with the needs of increasing populations. These conditions are exacerbated by local geomorphological and hydrodynamic conditions such as enclosed basins and low flushing rates. Examples of dead zones which appear to have formed recently are the Baltic Sea, the Black Sea, the Gulf of Mexico, and the East China Sea. Bricker et al. (2007) and Xiao et al.( 2007) characterize eutrophic conditions in the East China Sea, reporting observations of acute toxic blooms since the 1990s, and in Jiaozhou Bay, which drains into the Yellow Sea, toxic blooms have been reported since the 1960s. Where monitoring has occurred for a sufficiently long time, hypoxia appears to have increased significantly over the past approximate 50 years, similar to the very pronounced increase in nitrogen influxes and hypoxia in the Chesapeake Bay in the mid twentieth century.

Paleoecological records have been compiled for some hypoxic coastal areas in order to determine the onset of hypoxia, whether or not hypoxic events since the middle of the twentieth century are unique, and possible historical causes. For example, lead-210-dated sediment cores collected in the northern Gulf of Mexico, into which the Mississippi River flows, show that phytoplankton production, as well as other chemical indicators of hypoxia, increased sharply in the mid twentieth century (Rabalais et al. 2007). The most severe hypoxic events coincide with land clearance, agricultural expansion, land drainage, and the reduction of denitrification in the drainage area. Analysis of ecosystem indicators from areas draining into Laajalahti Bay in Finland, a part of the north Baltic Sea, records the history of pollution, beginning with preindustrial time (prior to 1815), followed by decreasing water quality with the increase in humans from around 1900 to 1955 and acute pollution from about 1955 to 1975 (Kauppila et al. 2005). The accelerated decrease in water quality was caused by increasing agriculture and in some estuaries also the discharge of waste water. Clarke et al. (2006) studied paleoecological records of fjords in Denmark. In one case, total nitrogen increased by $85 \%$ during the last century, with the greatest and most rapid increase happening after the 1950s, corresponding with the use of artificial fertilizers in Denmark. Paleoecological studies of another fjord in Denmark (Clarke et al. 2006) show an increase, in the mid 1980s, in total dissolved nitrogen inferred from the diatom record and sedimentary chlorophyll A, which coincides in this case with the discharge of sewage waste water between the mid 1950s and 1986. In 1986, the waste water discharge was removed, and water quality improved somewhat.

Cloern (2001) proposed that the intensity of coastal eutrophication is influenced by tidal energy, horizontal transport processes, which determine flushing rates and residence time, and light characteristics. Existing paleoecological records show that the extent and degree of eutrophication in coastal regions is related to the geomorphological-hydrologic characteristics of the basins, which alter the effect of excess nutrients through flushing rates (residence time) and also the strength of water column stratification. But recent monitoring also indicates that because of the length of time and chronic nature of nutrient inputs from agricultural fields, eutrophication effects are spreading from near-shore areas and semi-enclosed basins to offshore regions. Spreading anoxia/hypoxia into these regions may have contributed to major changes in fisheries populations, which have also been altered by overfishing and the introduction of invasive species (Diaz and Rosenberg 2008).

There are some instances of varying degrees of recovery. The reduction in intensity of hypoxia in the Black Sea in the mid twentieth century is synchronous with a two- to fourfold reduction in fertilizers from the Soviet Union at that time (Diaz and Rosenberg 2008). Management of nutrients has eliminated or greatly reduced dead zones in the Hudson and East Rivers along the east coast of the USA and also the Mersey and Thames estuaries in England (Diaz and Rosenberg 2008). Bricker et al. (2007) report improvement in a number of coastal areas following large 
reductions in nitrogen loads, including Moreton Bay, Australia, the Venice Lagoon, Italy, and in the USA Tampa Bay, Florida, Long Island Sound, New York, and the upper Potomac River in Maryland and Virginia. In all of these cases, improvements have been accomplished by reducing point-source pollutants, which may or may not have a lasting effect, due to the increasing dominance of nonpoint sources as coastal populations continue to grow (Bricker, personal communication).

Existing historical, long-term monitoring, and paleoecological records indicate that around the middle of the twentieth century, there was a unique and sudden shift to a new phase of eutrophication in Chesapeake Bay and other coastal systems. The loss of many species of submerged macrophytes in most of the tributaries of the Chesapeake Bay has been recorded both in historical monitoring and paleoecological records (Brush and Hilgartner 2000; Kemp et al. 2005). Zimmerman and Canuel (2002) describe increased abundances of dinoflagellates, cyanobacteria, and small flagellates during the last part of the twentieth century in the Chesapeake Bay, based on pigments preserved in sediment cores. Hagy et al. (2004) report that the volume of hypoxic water in mid summer in the Chesapeake Bay increased by at least three times between 1950 and 2001, based on approximately 50-year synchronous records of estuarine bottom water dissolved oxygen and watershed nitrate loading in the Bay. Almost all longterm monitoring and paleoecological records show humandriven increases in nitrogen loads to coastal systems since around the 1950s.

Sediment cores from Europe also show that where fertilizers are the primary source of nutrients, there has been a pronounced shift to greater hypoxia from the middle to the latter part of the twentieth century (e.g., Clarke et al. 2006). There are variations among different estuaries related to local geomorphology, hydrodynamics, and human activities. However, the majority of evidence indicates that increased hypoxia beginning in the mid twentieth century is a globally distributed phenomenon, reflecting intense eutrophication in many coastal ecosystems. Recent analyses suggest that large-scale depletion of bottom water oxygen drives changes in the system state that tend to accelerate nitrogen regeneration and alter the overall nitrogen cycle (e.g., Kemp et al. 2005; Conley et al. 2007). It is important to find out if indeed this is a worldwide change and if so, what it really means with respect to the structure and composition of future coastal ecosystems.

\section{Looking Ahead}

What can be done? Diaz and Rosenberg (2008) succinctly advise that "the key to reducing dead zones will be to keep fertilizers on the land and out of the sea." But how? It is not possible to restore the landscape to precolonial conditions. One of the initial responses to reversing aquatic deterioration was the planting of vegetation in riparian areas that would prevent nitrogen from the land reaching the streams and eventually estuaries and coastal regions. In addition, there were calls for best management agricultural practices such as reduced and precision fertilizer use and no-till farming. All of these practices would be expected to be helpful, but so far, have not proven effective. This failure was demonstrated by the findings of Harding et al. (1998) who compared the diversity of stream invertebrates in watersheds in North Carolina with different histories of land use. Results of their study indicated that the long-term history of agricultural land use resulted in changes in stream invertebrate diversity that were not restored by more recent riparian reforestation, at least not on the time scale of years to decades. The legacy of fertilizers applied to agricultural fields decades ago on nitrogen cycling in today's forests has been documented (e.g., Compton and Boone 2000) and modeled (Magill et al. 2000). More recently, expensive and extensive stream restoration projects aimed at restoring streams to their "natural" state by removing agricultural legacy sediments, which tend to separate the stream from the floodplain as well as increasing conditions for low velocity flow by creating riffles and pools that increase hydraulic retention, are aimed at improving aquatic water quality (Craig et al. 2008.) It remains to be seen how effective these projects are. Kaushal et al. (2008) showed that when streams were restored so that the stream channels are connected with the floodplain, denitrification rates increased, but they also cautioned that there is much variability in the efficiency of stream restoration designs. Mulholland et al.( 2008) in a study that included 72 streams in eight regions showed that although biological nitrate uptake and denitrification increased with stream nitrate concentration in agricultural and urban streams, they declined as concentrations increased beyond a certain threshold. They showed that at low nitrogen loading rates, biotic nitrogen removal was high and occurred primarily in the smaller streams; at moderate loading rates, removal in small streams decreased and that which was not removed migrated into the larger streams where it could be removed, but at high loading rates, removal became ineffective across all stream sizes.

Intuitively, it seems possible and appropriate to design a system for nitrogen cycling on today's landscape that mimics the function of the precolonial wet and marshy condition, where denitrification occurred throughout the watershed and was not confined to riparian areas. Suggestions have been made as to how this can be accomplished. Remote sensing has provided inputs to models that allow optimal areas for denitrification on the landscape to be 
identified (Kulkarni et al. 2008). Seitzinger et al. (2006) proposed watershed strategies for disposing of nitrogen, including reduction of drainage from agricultural lands. Recently, the states within the Chesapeake watershed have proposed a tributaries plan that includes augmenting nitrate uptake and denitrification throughout the watershed (Maryland's Chesapeake Bay Tributary Strategy Statewide Implementation Plan 2008). The recommendations are wide ranging. In addition to increasing opportunities for denitrification, nitrogen loads would be reduced using precision agriculture and cover crops, upgrading waste water treatment plants to enhance nutrient removal, improved management of animal waste, reducing and retrofitting impervious surfaces, retrofitting septic systems to include enhanced denitrification, reducing suburban sprawl, and restoring wetlands.

Other possibilities include planting forest stands on appropriate soils throughout the watershed. McNeil et al. (2008) have shown that the spatial pattern of nitrogen cycling in the canopy biomass of forests in the Adirondacks identified by remote sensing is related to species functional traits, nitrogen deposition, and historic disturbance. Lovett et al. (2002) showed that although nitrate leaching is strongly related to the carbon nitrogen ratio $(\mathrm{C} / \mathrm{N})$ of the watershed soils, vegetation can play an important part in the $\mathrm{C} / \mathrm{N}$ ratio in the soil, e.g., nitrogen leaching from soils into streams was greater in sugar maple forests than in red oak forests in the Catskills of New York. The paleoecological record of the Chesapeake system indicates that nitrogen influxes did not increase in the estuary until approximately $40 \%$ of the land was deforested. Runoff from agricultural fields could be decreased by surrounding fields with retention ditches with circulating water. Not only would such structures decrease runoff into adjacent streams but also, if anerobic conditions were present, would provide denitrifying sites. Wetlands situated in all hydrologically feasible locations throughout the watershed would also increase its denitrifying capacity by large amounts.

Removing nitrogen from the environment is an expensive proposition and presently is aimed primarily at restoring the estuarine and coastal fishery. But the desires and needs of human populations have changed so that the decision to proceed with the many tools that might improve coastal systems is also a political choice. For example, the composition of the Chesapeake population has changed from a majority of watermen relying for their living on fish and shellfish harvests to a population of residents, many of whom are commuters who value the estuary for its aesthetics and recreation more than as a food resource. The future of the Chesapeake and coastal regions in general will depend very much on the recognition of the importance of nitrogen removal for goals other than restoring the fishery, how successful the various tools for nitrogen removal are, and the willingness of the public to pay for the implementation of those tools that can successfully achieve multiple goals.

Acknowledgments I thank Mike Martin for drafting Fig. 2 and Emily Elliott, Walter Boynton, Suzanne Bricker, Michael Kemp, and Charles O'Melia for comments on the manuscript.

\section{References}

Andrews, E. 2008. Land cover: Chesapeake Bay watershed. Chesapeake Bay Program National Land Cover Data 2001. www. chesapeakebay.net

Arnold, A.M. 2003. An interglacial (Sangamon) and late Holocene record of Chesapeake Bay. Ph. D. dissertation, Johns Hopkins University, Baltimore, Md. 269 pp

Bayley, S., V.D. Stotts, P.F. Springer, and J. Steenis. 1975. Changes in submerged macrophyte populations at the head of Chesapeake Bay, 1958-1975. Estuaries 1: 171-182. doi:10.2307/1351459.

Bricker, S.B., B. Longstaff, W. Dennison, A. Jones, K. Boicourt, C. Wicks, and J. Woerner. 2007. Effects of nutrient enrichment in the nation's estuaries: a decade of change. NOAA Coastal Ocean Program Decision Analysis Series No. 26, 322 pp. Maryland: Silver Spring.

Brugger, R.J. 1988. Maryland: a middle temperament. Baltimore: Johns Hopkins University Press.

Brush, G.S. 1984. Patterns of recent sediment accumulation in Chesapeake Bay (Virginia-Maryland, USA) tributaries. In Geochronology of recent deposits, ed. J.A. Robbins, Chemical Geology 44: 227-242. doi:10.1016/0009-2541(84)90074-3

Brush, G.S. 1989. Rates and patterns of estuarine sediment accumulation. Limnology and Oceanography 34: 1235-1246.

Brush, G.S., and W.B. Hilgartner. 2000. Paleoecology of submerged macrophytes in the upper Chesapeake Bay. Ecological Monographs 70: 645-667.

Brush, G.S., E.A. Martin, R.S. DeFries, and C.A. Rice. 1982. Comparisons of $210 \mathrm{~Pb}$ and pollen methods for determining rates of estuarine sediment accumulation. Quaternary Research 18: 196-217. doi:10.1016/0033-5894(82)90070-9.

Clarke, A.L., K. Weckstrom, D.J. Conley, N.J. Anderson, F. Adser, E. Andren, V.N. deJonge, M. Ellegaard, S. Juggins, P. Kauppila, A. Korhala, N. Reuss, R.J. Telford, and S. Vaalgamaa. 2006. Longterm trends in eutrophication and nutrients in the coastal zone. Limnology and Oceanography 511, part 2: 385-397.

Cloern, J.E. 2001. Our evolving conceptual model of the coastal eutrophication problem. Marine Ecology Progress Series 210: 223-253. doi:10.3354/meps210223.

Compton, J.E., and R.D. Boone. 2000. Long-term impacts of agriculture on soil carbon and nitrogen in New England forests. Ecology 81: 2314-2330.

Conley, D.J., J. Carstensen, G. Ærtebjerg, P.B. Christensen, T. Dalsgaard, J.L.S. Hansen, and A.B. Josefson. 2007. Long-term changes and impacts of hypoxia in Danish coastal waters. Ecological Applications 17: S165-S184. doi:10.1890/05-0766.1.

Cooper, S.R. 1993. A 2,500 year history of anoxia and eutrophication in Chesapeake Bay. Estuaries 16: 617-626. doi:10.2307/ 1352799.

Cooper, S.R. 1995. Chesapeake Bay watershed historical land use: impacts on water quality and diatom communities. Ecological Applications 5: 703-723. doi:10.2307/1941979.

Cooper, S.R., and G.S. Brush. 1991. Long-term history of Chesapeake Bay anoxia. Science 254: 992-996. doi:10.1126/sci ence.254.5034.992. 
Cornwell, J.C., D.J. Conley, M. Owens, and J.C. Stevenson. 1996. A sediment chronology of the eutrophication of Chesapeake Bay. Estuaries 19: 488-499. doi:10.2307/1352465.

Craig, L.S., M.A. Palmer, D.C. Richardson, S. Filoso, E.S. Bernhardt, B.P. Bledsoe, M.W. Doyle, P.M. Groffman, B.A. Hassett, S.S. Kaushal, P.M. Mayer, S.M. Smith, and P.R. Wilcock. 2008. Stream restoration strategies for reducing river nitrogen loads. Frontiers in Ecology and the Environment 6. doi:10.1890/ 070080.

Cronin, L.E. 1986. Chesapeake fisheries and resource stress in the nineteenth century. Journal of the Washington Academy of Sciences 76: 188-198.

Craven, A.O. 1965. Soil exhaustion as a factor in the agricultural history of Virginia and Maryland, 1606-1680. Gloucester: Peter Smith. (reprinted from 1926).

Diaz, R.J., and R. Rosenberg. 2008. Spreading dead zones and consequences for marine ecosystems. Science 321: 926-929. doi:10.1126/science. 1156401 .

Douglas, H.T. 1897. Atlas of the City of Baltimore, Md. Baltimore Topgraphical Survey.

Earle, C. 1992. Into the abyss...again: technical change and destructive occupance in the American Cotton Belt, 1870-1930. In The American Environment, eds. L.M. Dilsaver, and C.E. Colton, 53-88. Lanham, Maryland: Rowman and Littlefield.

Elliott, E.M., and G.S. Brush. 2006. Sedimented organic nitrogen isotopes in freshwater wetlands record long-term changes in watershed nitrogen source and land use. Environmental Science and Technology 40: 2910-2916. doi:10.1021/es051587q.

Elliott, E.M., C. Kendall, S.D. Wankel, D.A. Burns, E.W. Boyer, K. Harlin, D.J. Bain, and T.J. Butler. 2007. Nitrogen isotopes as indicators of $\mathrm{NO}_{\mathrm{x}}$ source contributions to atmospheric nitrate deposition across the Midwestern and Northeastern United States. Environmental Science and Technology 41: 7661-7667. doi:10.1021/es070898t.

Froomer, N.L. 1980. Morphologic changes in some Chesapeake Bay tidal marshes resulting from accelerated soil erosion. Zeitschrift fur Geomorphologie N. F. Supplement-Bd 34: 242-254.

Galloway, J.N., F.J. Dentener, D.G. Capone, E.W. Boyer, R.W. Howarth, S.P. Seitzinger, G.P. Asner, C.C. Cleveland, P.A. Green, E.A. Holland, D.M. Karl, A.F. Michaels, J.H. Porter, A. R. Townsend, and C.J. Vorosmarty. 2004. Nitrogen cycles: past, present, and future. Biogeochemistry 70: 153-226. doi:10.1007/ s10533-004-0370-0.

Gottschalk, L.C. 1945. Effects of soil erosion on navigation in upper Chesapeake Bay. Geographical Revue 35: 219-237.

Groffman, P., N.J. Boulware, W.C. Zipperer, R.V. Pouyat, L.E. Band, and M.F. Colosimo. 2002. Soil nitrogen processes in urban riparian zones. Environmental Science and Technology 36: 45474552. doi:10.1021/es020649z.

Groffman, P., D.J. Bain, L.E. Band, K. Belt, G.S. Brush, J.M. Grove, R.V. Pouyat, I.C. Yesilonis, and W.C. Zipperer. 2003. Down by the riverside: urban riparian ecology. Frontiers in Ecology and the Environment 1: 315-321.

Hagy, J.D., W.R. Boynton, C.W. Keefe, and K.V. Wood. 2004. Hypoxia in Chesapeake Bay: long-term change in relation to nutrient loading and river flow. Estuaries 27: 634-658.

Harding, J.S., E.F. Benfield, P.V. Bolstad, G.S. Helfman, and E.B.D. Jones. 1998. Stream biodiversity: the ghost of land use past. Proceedings of the National Academy of Science 95: 1484314847. doi:10.1073/pnas.95.25.14843.

Jaworski, N.A., B. Romano, C. Buchanan, and C.L. Jaworski. 2007. The Potomac River Basin and its Estuary: landscape loadings and water quality trends, 1895-2005. http://www.umces.edu/presi dent/Potomac

Kauppila, P., K. Weckstrom, S. Vaalgamaa, A. Korhola, H. Pitkanen, N. Reuss, and S. Drew. 2005. Tracing pollution and recovery using sediments in an urban estuary, northern Baltic Sea: are we far from ecological reference conditions? Marine Ecology Progress Series 290: 35-53. doi:10.3354/meps290035.

Kaushal, S.S., P.M. Groffman, P.M. Mayer, E. Striz, and A.J. Gold. 2008. Effects of stream restoration on denitrification in an urbanizing watershed. Ecological Applications 183: 789-804. doi:10.1890/07-1159.1.

Kemp, W.M., W.R. Boynton, J.E. Adolf, D.F. Boesch, W.C. Boicourt, G. Brush, J.C. Cornwell, T.R. Fisher, P.M. Glibert, J.D. Hagy, L.W. Harding, E.D. Houde, D.G. Kimmel, W.D. Miller, R.I.E. Newell, M.R. Roman, E.M. Smith, and J.C. Stevenson. 2005. Eutrophication of Chesapeake Bay: historical trends and ecological interactions. Marine Ecology Progress Series 303: 1-29. doi:10.3354/ meps303001.

Kennedy, V.S., and K. Mountford. 2001. Human influences on aquatic resources in the Chesapeake Bay watershed. In Discovering the Chesapeake: the history of an ecosystem, eds. P.D. Curtin, G.S. Brush, and G.W. Fisher, 191-219. Baltimore: Johns Hopkins University Press.

Khan, H., and G.S. Brush. 1994. Nutrient and metal accumulation in a freshwater tidal marsh. Estuaries 17: 345-360. doi:10.2307/1352668.

Kulkarni, M., P.M. Groffman, and J.B. Yavitt. 2008. Solving the global nitrogen problem: it's a gas. Frontiers in Ecology and the Environment 6: 199-206. doi:10.1890/060163.

Lovett, G.M., K.C. Weathers, and M.A. Arthur. 2002. Control of nitrogen loss from forested watersheds by soil carbon:nitrogen ratio and tree species composition. Ecosystems 5: 712-718. doi:10.1007/s10021-002-0153-1.

Magill, A.H., J.D. Aber, G.M. Bernston, W.H. McDowell, K.J. Nadelhoffer, J.M. Melillo, and P.A. Steudler. 2000. Long-term nitrogen additions and nitrogen saturation in two temperate forests. Ecosystems 3: 238-253. doi:10.1007/s100210000023.

McNeil, B.E., J.M. Read, T.J. Sullivan, T.C. McDonnell, I.J. Fernandez, and C.T. Driscoll. 2008. The spatial pattern of nitrogen cycling in the Adirondack Park, New York. Ecological Applications 18: 438-452. doi:10.1890/07-0276.1.

Miller, H.M. 2001. Living along the Great Shellfish Bay: the relationship between prehistoric peoples and the Chesapeake. In Discovering the Chesapeake: the history of an ecosystem 2001, eds. P.D. Curtin, G.S. Brush, and G.W. Fisher, 109-126. Baltimore: Johns Hopkins University Press.

Morgan, L.H. 1867. The American beaver and his works. New York: Burt Franklin. (reprinted 1970).

Mulholland, P.J., A.M. Helton, G.C. Poole, R.O. Hall Jr, S.K. Hamilton, B.J. Peterson, J.L. Tank, L.R. Ashkenas, L.W. Cooper, C.N. Dahm, W.K. Dodds, S.E.G. Findlay, S.V. Gregory, N.B. Grimm, S.L. Johnson, W.H. McDowell, J.L. Meyer, H.M. Valett, J.R. Webster, C. P. Arango, J.J. Beaulieu, M.J. Bernot, A.J. Burgin, C.L. Crenshaw, L.T. Johnson, B.R. Niederlehner, J.M. O’Brien, J.D. Potter, R.W. Sheibley, D.J. Sobota, and S.M. Thomas. 2008. Stream denitrification across biomes and its response to anthropogenic nitrate loading. Nature 452: 202-205. doi:10.1038/nature06686.

Naiman, R.J., C.A. Johnston, and J.C. Kelley. 1988. Alteration of North American streams by beaver. Bioscience 38: 753-762. doi: $10.2307 / 1310784$.

Pasternack, G.B., and G.S. Brush. 1998. Sedimentation cycles in a river-mouth tidal fresh water marsh. Estuaries 21: 407-415. doi: $10.2307 / 1352839$.

Rabalais, N.N., R.E. Turner, B.K. Sen Gupta, E. Platon, and M.L. Parsons. 2007. Sediments tell the history of eutrophication and hypoxia in the northern Gulf of Mexico. Ecological Applications 175: S129-S143. doi:10.1890/06-0644.1.

Richter, D.D., and D. Markewitz. 2001. Understanding soil change. New York: Cambridge University Press.

Rybicki, N.B., and J.M. Landwehr. 2007. Long-term changes in abundance and diversity of macrophyte and waterfowl popula- 
tions in an estuary with exotic macrophytes and improving water quality. Limnology and Oceanography 52: 1195-1207.

Seitzinger, S., J.A. Harrison, J.K. Bohlke, A.F. Bouwman, R. Lowrance, B. Peterson, C. Tobias, and G. Van Drecht. 2006. Denitrification across landscapes and waterscapes: a synthesis. Ecological Applications 16: 2064-2090. doi:10.1890/1051-0761 (2006)016[2064:DALAWA]2.0.CO;2.

Selman, M., S. Greenhalgh, R. Diaz, and Z. Sugg. 2008. Eutrophication and hypoxia in coastal areas: a global assessment of the state of knowledge. WRI Policy Note no. 1: 1-6.

Sprague, E., D. Burke, S. Claggett, and A. Todd, eds 2006. The State of Chesapeake Forests. The Conservation Fund.

Stankelis, R.M., M.D. Naylor, and W.R. Boynton. 2003. Submerged aquatic vegetation in the mesohaline region of the Patuxent Estuary: past, present, and future status. Estuaries 26: 186-195.

Stevenson, J.C., J.I. Marusic, B. Ozreetic, A. Marson, G. Cecconnii, and M.S. Kearney. 1999. Shallow water and shoreline ecosystems of the Chesapeake Bay compared to the northern Adriatic Sea: transformation of habitat at the land-sea margin. In Ecosystems at the landsea margin: drainage basin to coastal sea, eds. T. Malone, A. Malej, L.W. Harding Jr, N. Smodlaka, and R.E. Turner, 29-76. Washington, D.C.: American Geophysical Union.

Ubelaker, D.H., and P.D. Curtin. 2001. Human biology of populations in the Chesapeake watershed. In Discovering the Chesapeake: the history of an ecosystem, eds. P.D. Curtin, G.S. Brush, and G. W. Fisher, 127-148. Baltimore: Johns Hopkins University Press.

U. S. Bureau of the Census, Census Data for Years 1850-1975, Washington, D.C.: Department of Commerce.
U. S. Environmental Protection Agency (USEPA). Chesapeake Bay program office, Annapolis, Maryland. http://www.chesapeake bay.net.

Vitousek, P.M., J.D. Aber, R.W. Howarth, G.E. Likens, P.A. Matson, D.W. Schindler, W.H. Schlesinger, and D.G. Tilman. 1997. Human alteration of the global nitrogen cycle: sources and consequences. Ecological Applications 73: 737-750.

Vokes, H.E., and J.E. Edwards. 1974. Geography and geology of Maryland. Maryland Geological Survey Bulletin 19. Baltimore: Maryland Geological Survey.

Walsh, L.S. 1989. Plantation management in the Chesapeake 1620 1820. Journal of Economic History 49: 393-406.

Walsh, L.S. 1992. Chesapeake planters and the international market, 1770-1820. In The Chesapeake and beyond: a celebration, ed. L.G. Carr, 205-227. Crownsville: Maryland Historical and Cultural Publications.

Wolman, M.G. 1967. A cycle of sedimentation and erosion in urban river channels. Geografiska Annaler 49A: 385-395. doi:10.2307/520904.

Xiao, Y., J.G. Ferreira, S.B. Bricker, J.P. Nunes, M. Zhu, and X. Zhang. 2007. Trophic assessment in Chinese coastal systemsreview of methods and application to the Changjiang (Yangtze) Estuary and Jiaozhou Bay. Estuaries and Coasts 306: 901-918.

Yuan, S. 1995. Postglacial history of vegetation and river channel geomorphology in a Coastal Plain floodplain. Ph. D. dissertation, Johns Hopkins University, Baltimore, Md. 164 pp.

Zimmerman, A.R., and E.A. Canuel. 2002. Sediment geochemical records of eutrophication in the mesohaline Chesapeake Bay. Limnology and Oceanography 47: 1084-1093. 